\title{
CONTENT BASED INSTRUCTION IN TEACHING TOURISM AND ECONOMICS COURSES
}

\author{
Abror Juraev \\ Tolib Sobirov \\ Bukhara State University, Uzbekistan
}

\begin{abstract}
Recent years in higher education system of Uzbekistan witnessed deep reforms related with increasing the quality of education, better employment of graduates, improvement of foreign languages competences and strengthening the links in the knowledge triangle. When some universities started offering specialization courses in English or other languages, problem of matching objectives of the courses with the aim of improving English language competence came to agenda. The article depicts the situation at newly created Faculty of Tourism at Bukhara State University and the use of Content-Based Instruction in finding the solution. The new faculty consists of BA and MA degrees in fields related with Tourism, Hospitality, Economics, Fine Arts etc.
\end{abstract}

Keywords: content-based instruction, foreign languages, teaching methodologies.

\section{Introduction}

Bukhara State University (BSU), being one of the oldest and biggest universities in Uzbekistan, was founded in 1930 as a higher educational institution aimed at preparation of teaching staff for the schools of the region. Now composed of 8 faculties with nearly 500 academic staff and 6400 students, BSU is among the top universities in the Central Asia with regards to number of European Union's TEMPUS, Erasmus Mundus and Erasmus ${ }^{+}$projects, aimed at the development of education sphere, implementing quality assurance initiatives, higher education management etc. Using IT in university management, improvement of foreign language knowledge and internationalization are among the main strategic tasks of the university.

In parallel with governmental reforms in internationalization of the higher education, teaching of 10 courses in English started from 2013-2014 academic year, while there were individual cases before. Now the number of courses offered in English is constantly growing.

With the start of commencing the specialization courses in English, mostly at the Department of Tourism, there was a search for efficient methods in combining field-related competences with the English language competences. 
Later, with the creation of separate faculty of Tourism that covered some other degree fields in its structure, led to search for need for methods that would be useful also in other field. Content-Based Instruction (CBI) could serve as a starting point, so it was used in some courses. In our article, we tried to analyze the situation at the Faculty of Tourism, with specific attention to the educational objectives and results.

\section{Background of the topic}

With the start of offering specialization courses in English, academic staff of Department of Tourism faced some issues related with combining English competences with specific course aims. There were 4 ways of conducting courses in English.

1. Teaching the course entirely in English. The issues of concern were: a) are the students ready for this? b) are the teachers ready for this?

Students of the courses had taken English test as one of the parts of entrance examinations and then continued to English courses, but their competence was more grammar centered, rather than practical use of the language. Although staffs responsible for the selected courses possess well enough English competence, target groups of students would definitely have problems in taking whole courses in English. Thus aim of the course was difficult or almost impossible to reach.

2. Teaching the course in simplified way. Simple English could be used for the conduction of the lectures, but the problem was how to cover the study plans of the courses, how to achieve the educational objectives and the expected results.

3. Teaching some parts of the course in English, some parts in Uzbek. This method may lead to a problem of assuring continuity of the experiment.

4. Teaching in native language and explaining important terms in English would enrich vocabulary knowledge, but not the teaching content and competence of students.

A need for the most effective way of teaching resulted in selection of Content-Based Instruction as the most appropriate methodology.

\section{Rationale for Content-Based Instruction (CBI)}

Brinton, Snow and Wesche (2003) have defined some reliable rationale for CBI. Firstly, CBI removes the arbitrary distinction between language and content. The second, it reflects the interests and the needs of the learners. Third, it takes into account the eventual uses of the learners will to make use of the foreign language. It exposes the learners to authentic materials and tasks. Fourth, it offers optimal conditions for second language acquisition by exposing learners to meaningful, cognitively demanding language. Last but not the least, and the most 
important in conducting specialization courses, it provides pedagogical accommodation to learner proficiency levels and skills.

Savichuk (2010) underlines that CBI has become increasingly popular as a means of developing linguistic ability in a great variety of educational contexts. The philosophy of this methodological paradigm aims at encouraging students to learn a new language by using it from the first class as a real means of communication.

Using content-based instruction not only in language teaching, but also reversely, in teaching different courses in foreign language focuses on what is being taught through the language. Language becomes the medium through which something new is learned. Students learn the foreign language while using it to learn new content in Tourism, Economics etc. The language being learned and used becomes taught within the context of the content. The theory behind CBI is that when students are engaged with more content, it will promote their motivation. Students will be able to use more advanced thinking skills when learning new information. This approach is very student-centered as it depends entirely on the students' ability to use the language.

Grabe and Stoller (1997) define CBI as a tool to keep students motivated and interested. Motivation and interest are crucial in supporting student success with challenging, informative activities that support success and which help the student learn complex skills. Krapp, Hidi and Renninger (1992) state that when students are motivated and interested in the material they are learning, they make greater connections between topics, elaborations with learning material and can recall information better.

In leaner-centered groups students acquire skills and knowledge through doing and they are actively involved in the learning process. Teacher is not the only source of the information. Lee and Van Patten (1995) underline that students assume active, social roles in the classroom that involve interactive learning, negotiation, information gathering and the co-construction of meaning.

\section{The Role of Teaching Staff in Using CBI}

According to Stryker and Leaver (1993), teachers play the following role during CBI lessons:

1. They must be knowledgeable in the subject matter and able to elicit that knowledge from their learners.

2. Teachers are responsible for selecting and adapting authentic materials for use in class.

3. Teachers must create truly learner-centred classroom.

4. Teachers must keep context and comprehensibility foremost in their planning and presentation. 
5. Teachers must contextualize their lessons by using content as their point of departure.

Teachers should clearly define if their courses will be more language-driven or content-driven. In teaching Tourism and Economics courses, they tend to and should be more content-driven.

Materials used in CBI lessons are very important. Stryker and Leaver (1993) state the characteristics of CBI material as follows:

1. Material must be authentic - like the ones used in native language instructions.

2. Examples must be drawn from realia and real life experience and contemporary issues.

\section{Content integration in teaching Tourism and Economics Courses}

In teaching courses in the field of Tourism and Economics in English, there are many things that can be considered as "content". The most important thing is that what you are teaching or discussing in English must be the course-related, not the language-learning related. Discussions about current news, case-studies, statistical data, indicators all valid "content" options.

There is a need for integration of the content and the foreign language. Stoller (2002) states 8 practices that allow for natural content integration:

1. Extended input, meaningful output, and feedback on language and grasp of content.

2. Information gathering, processing, and reporting.

3. Integrated skills (using reading, writing, speaking and listening in natural classroom activities).

4. Task-based activities and project work, enhanced by cooperative learning principles.

5. Strategy training (to produce more metacognitively aware strategic learners).

6. Visual support (ie. Images, graphic organizers, language ladders etc.).

7. Contextualized grammar instruction.

8. Culminating synthesis activities (knowledge is displayed in writing and orally).

Finkenstein and others (2010) propose the following logic model in contentbased economic instruction. 


\begin{tabular}{|c|c|c|}
\hline $\begin{array}{c}\text { Teacher Professional } \\
\text { Development }\end{array}$ & $\begin{array}{l}\text { Classroom } \\
\text { Instruction }\end{array}$ & $\begin{array}{c}\text { Student } \\
\text { Performance }\end{array}$ \\
\hline $\begin{array}{l}\text { Content } \\
\text { Review of economic } \\
\text { theory and related } \\
\text { applications; } \\
\text { curriculum review }\end{array}$ & $\begin{array}{l}\text { Curriculum } \\
\text { Fluent presentation } \\
\text { of curriculum; } \\
\text { scaffolding for } \\
\text { students }\end{array}$ & $\begin{array}{l}\text { Concepts } \\
\text { Broad-based literacy } \\
\text { in micro- and } \\
\text { macroeconomic } \\
\text { concepts }\end{array}$ \\
\hline $\begin{array}{l}\text { Pedagogy } \\
\text { Problem-based } \\
\text { approach to } \\
\text { teaching and } \\
\text { support strategies } \\
\text { for students }\end{array}$ & $\begin{array}{l}\text { Engagement } \\
\text { Problem-solving } \\
\text { strategies that build } \\
\text { economic content and } \\
\text { reinforce core } \\
\text { analytic thinking }\end{array}$ & $\begin{array}{l}\text { Problem Solving } \\
\text { Ability to } \\
\text { apply concepts } \\
\text { and analytic } \\
\text { approaches to } \\
\text { real-world problems }\end{array}$ \\
\hline
\end{tabular}

Figure 1 Logic model in content-based economic instruction

\section{CBI in Faculty of Tourism, BSU}

After commencement of some courses in English, like World Economy and International Economic Relations, Tourism Marketing, Economics of Tourism, CBI became a very efficient tool for the teaching staff.

Different methods were used in for instance in the course of World Economy and International Economic Relations, mostly in seminar classes:

1. Students are divided into 3 groups, 6-7 persons in each. 3 ideas for discussion are distributed. For example:

- $\quad$ Introducing a single currency will lead to economic benefits

- $\quad$ Protectionism is good for the developing economies

- Economic crises stimulate innovations.

After 15 minutes, one student per group has to make a speech in English, showing 5 arguments at least, that defend the idea of the discussion. Points are given according to the presentation manners, reliability of arguments, theoretical knowledge, awareness of the current economic situation etc.

2. Latest data on commodities oil, gold, silver, etc. are shown to students, by entering Internet at seminars time. Data is used from www.nasdaq.com, www.bloomberg.org, www.ereport.ru, www.chartsbin.com, etc.

Students are asked to make their predictions, using the information they have about current trends in the world economy. After 2 weeks, new data is derived, compared with the old one, students are asked to explain the reasons of changes. 


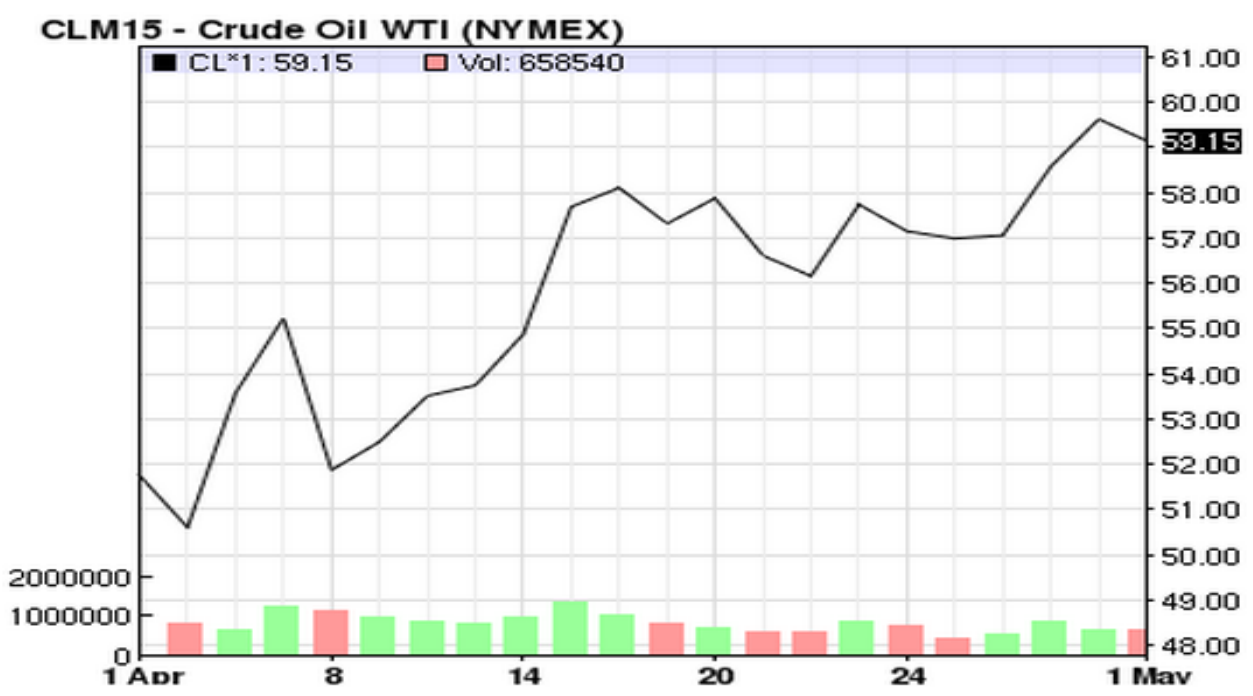

Figure 2 An example of "content" in economic courses

3. Students are divided into 2-4 groups. Latest data on market shares or marketing strategies or new products of 2-4 companies are found from the web. In 2 weeks time, groups will prepare information about activities of one company each and will present their view of the situation, characteristics of company products, measures they would implement to increase the share.

Hottest discussions, as predicted, were between Android - iOS groups, Beeline-Ucell-UMS groups (biggest mobile providers in Uzbekistan), Coca Cola - Pepsi groups, Samsung - Apple groups.

Analyzes in the form of post-course questionnaires and grades at exams showed that using content-based methods in teaching "World Economy and International Economic Relations" course (partly in English, mostly seminars) led to:

- $\quad$ Better coverage of course contents

- $\quad$ Improved English skills

- Improved presentation skills

- Increased motivation of students

- Introduction to latest data

- Improved critical thinking

- $\quad$ Lack of sufficient English could be balanced by active involvement in group works.

A problem to solve appeared in the form of classical issue - differences between "leaders" and "sleeping" students. 


\section{Perspectives of CBI}

Together with degree programs in Tourism, Hotel Management, Economics, the Faculty of Tourism also has degree programs in Fine Arts and Crafts. Using $\mathrm{CBI}$ in teaching some specialization courses of these programs in English is also predicted to bring benefits.

Degree programs envisage courses in drawing, painting, sculpture, and various crafts-related disciplines (ceramics, metal, etc.). The growth in the number of international tourists arriving to Uzbekistan has created a need for better foreign language knowledge in all fields related with tourism. There is an increasing demand from students of Fine Arts and Crafts programs for English based courses, where CBI can be a very efficient and valuable methodology.

\section{Conclusions}

In our work we made a short overview of rationale and experiment of using CBI in Tourism and Economics courses taught at the Faculty of Tourism, Bukhara State University. In our experience, analysis of the process underlines the most attractive benefits of $\mathrm{CBI}$ as following:

1. CBI totally supports both learner and the teacher in delivering the content in the most real-life context;

2. CBI allows learners to proceed forward by acquiring specialized, as well as foreign language competences;

3. Being a learner-centered instruction, CBI brings better communicative skills;

4. Contents stimulate learners for better knowledge, they motivate and create interest, so allow to reach educational aims of the course;

5. Learners can make closer connection with foreign language and economic knowledge.

6. Greater flexibility and adaptability in the curriculum can be deployed as per the learners' interest.

7. Information search and re-evaluation of those resources help learners in developing valuable critical thinking skills;

8. Group works undoubtedly will lead to collaborative skills.

\section{References}

Briton, D., Snow, M. A., \& Wesche, M. B (2003). Content Language Instruction. University of Michigan Press.

Finkelstein, N., Hanson, T., Huang, C. W., Hirschman, B., \& Huang, M. (2010). Effects of Problem Based Economics on High School Economics Instruction. Final Report. NCEE 2010-4002. National Center for Education Evaluation and Regional Assistance. 
Grabe, W., \& Stoller, F. L. (1997). Content-based instruction: Research foundations. In M. A. Snow, \& D. M. Brinton (Eds.), The content-based classroom: Perspectives on integrating language and content (pp. 5-21). NY: Longman.

Krapp, Hidi, \& Renninger (1992). The Role of Interest in Learning and Development. Lawrence Erlbaum Associates, Hilldale, NJ.

Lee \& Van Patten (1995). Making Communicative Language Teaching Happen. McGraw-Hill. Savichuk, V. (2010). Linking Profession and Language: Content-Based Instruction in English for Specific Purposes to Hospitality and Tourism Students. Volyn National University, Ukraine.

Stoller, F. L. (2002). Content-Based Second Language Instruction: What is it? http://www.carla.umn.edu/cobaltt/CBI.html

Stryker \& Leaver (1993). Content-Based Instruction in Foreign Language Education: Models and Methods. Georgetown University Press. 